Man and Nature

L'homme et la nature

\title{
Musical Rhetoric and Other Symbols of Communication in Bach's Organ Music
}

\section{Jacobus Kloppers}

Volume 3, 1984

URI : https://id.erudit.org/iderudit/1011830ar

DOI : https://doi.org/10.7202/1011830ar

Aller au sommaire du numéro

Éditeur(s)

Canadian Society for Eighteenth-Century Studies / Société canadienne d'étude du dix-huitième siècle

ISSN

0824-3298 (imprimé)

1927-8810 (numérique)

Découvrir la revue

Citer cet article

Kloppers, J. (1984). Musical Rhetoric and Other Symbols of Communication in Bach's Organ Music. Man and Nature / L'homme et la nature, 3, 131-162.

https://doi.org/10.7202/1011830ar

Copyright (C Canadian Society for Eighteenth-Century Studies / Sociéte canadienne d'étude du dix-huitième siècle, 1984
Ce document est protégé par la loi sur le droit d'auteur. L'utilisation des services d'Érudit (y compris la reproduction) est assujettie à sa politique d'utilisation que vous pouvez consulter en ligne.

https://apropos.erudit.org/fr/usagers/politique-dutilisation/ 


\section{Musical Rhetoric and Other Symbols of Communication in Bach's Organ Music ${ }^{1}$}

This paper illustrates certain communicative devices in Bach's organ music. Such devices are usually designated by the term 'symbol.' This term is employed in the present paper in the broadest sense; it denotes a means to communicate something - directly and indirectly. This proviso is necessary since the word is most frequently used in a restricted sense to indicate an indirect form of musical communication, i.e., a musical sign which, representing something beyond itself, requires familiarity and abstract decoding before it is understood. In itself such a sign would be more or less neutral and the idea, which it represents, understood in the abstract, rather than experienced. There are, however, musical signs (symbols in a wider sense) which communicate ideas that do not require decoding. Concepts such as 'high, 'low, 'fast, 'slow, 'fear,' 'joy,' 'contrast,' 'repetition' and 'climax' have been experimentally proven to be directly visualized or experienced through musical sound without the need for any additional decoding or translation in the abstract.

It will be demonstrated that Bach's organ music makes use of both forms of communication: the direct manner employed in musical rhetoric, as well as the indirect process of rather esoteric symbols. Musical rhetoric will be illustrated by means of two of Bach's 'free' (textless) organ works, the other symbols by means of the textual chorale preludes (hymn arrangements). The chorale preludes will demonstrate that Bach usually transmits an idea in both ways simultaneously: through rhetoric and the creation of moods, as well as through the hid- 
den symbols of number, allegory, etc.. The paper will not attempt to prove the same duality for the free, textless organ music (Preludes, Fugues, Toccatas, etc.). Attempts have been made to discover various hidden symbols in Bach's keyboard Preludes and Fugues (semantics of number, number cabalistics, structural symbolism), but, although interesting statistics have emerged, the results remain somewhat speculative in the absence of any contextual reference (text association, liturgical context, etc.). The exception may be the 'St. Anne's' organ Prelude and Fugue (BWV 552) which act respectively as introduction to and conclusion of a set of liturgical chorale preludes (cf. below).

Essential for an understanding of the embodiment of symbols in Bach's organ music is a historical perspective. A brief survey will be given of the musical tradition and musical concepts from which such a practice sprung.

Finally, the paper does not intend to explain Bach's music completely in terms of rhetoric and other symbols or to suggest that symbols are present or equally prominent in each work. His music is, foremost, music to be enjoyed and analyzed in musical terms: theory, harmony, counterpoint, style, ornamentation and musical form. Rather the paper illustrates the extent to which these musical means were influenced by various non-musical symbolic concepts and that the idea of 'absolute music' or 'pure music' needs some qualification as far as Bach is concerned. With few exceptions his music was not written for aesthetic contemplation solely, but to fulfil a specific function. His sacred music served a didactic purpose within the Lutheran liturgical tradition. Although some of his later music moved in a more abstract direction, Bach did not subscribe to the notion of 'autonomous' or 'absolute' music which was later developed in the Classic era. Those who prefer to interpret Bach's music as absolute and non-referential are, nevertheless, correct in one regard: even when he applied rhetorical concepts within the traditional learned music style, the tonal means and sound impressions of his music remain intrinsically musical and musically satisfying.

\section{Musical rhetoric in Bach's organ music}

Since rhetoric is no longer practised widely or taught in our schools as a formal subject, a brief exposition of this art and its general application to music might clarify the subject matter.

Rhetoric is the art of using language so as to persuade or influence others; the body of rules to be observed by a speaker or writer in order 
that he may express himself with eloquence' (OED). It must be based on logic and dialectics yet it must also appeal to the emotions and passions of the hearers. The power of persuasion has undoubtedly been realized and intuitively practiced since the beginning of human history; it was formally recognized in the earliest Greek writings, it developed into a formal art during the Greek classical period, and it was refined by Aristotle, Cicero, Quintilian and others.

This art comprises four stages (Note: The following rhetorical terminology is that used in Germany during the times of Bach and deviates somewhat from Quintilian's and other writers' of Antiquity):

1) the collecting or finding of facts or material (Inventio); several resources, guidelines ('loci topici') exist for this purpose

2) the orderly arrangement, disposition of the material collected (Dispositio, Elaboratio): Exordium (introduction), Narratio (narration), Propositio (statement of view), Confirmatio and Confutatio (confirmation of view and refutation of opposite views by means of analysis), Peroratio (conclusion)

3) the use of the right words and emotional decoration or presentation of the facts (Decoratio, Ornatus), the creation of moods by means of more than 160 different tropes and figures, e.g., repetition, exclamation, rhetorical question, hyperbole, antithesis, emphasis, etc.

4) the memorizing and delivery of speech, the manner of presentation (Memoria; Elocutio, Pronuntiatio, Actio), by means of the proper articulation, emphasis, gestures and emotional involvement ${ }^{2}$

Music and rhetoric inherently have much in common. They

1) need time to be presented

2) consist of continual changes in their sound elements

3) have a beginning, logical continuation and peroration

4) employ rhythm, tempo, the pause, dynamics, repetition and antithesis

5) make use of the law of 'extending parts': statement, statement, extended statement

6) use analogical formulas, e.g., the comma ('imperfect' $=$ half-cadence or incomplete cadence in music), semicolon (fermata), period ('perfect' cadence, complete cadence), exclamation mark (deceptive cadence, interrupted chord)

7) need a reciter or orator (recitalist, performer) 
8) make use of moods and emotions

9) need articulation, phrasing and emphasis ${ }^{3}$

Translated into musical terms the four stages of rhetoric as they appeared during the times of Bach were:

1) the finding of a musical idea or motif. In textual music the words can serve as a guide with regard to the spirit of the work and the nature of the motifs and themes to be used.4 Several loci topici' (literally 'places' to find material for a musical 'topic') were suggested by Mattheson, a contemporary of Bach. ${ }^{5}$

2) the arrangement or disposition of the musical ideas.

Mattheson again quoted the arrangement of rhetoric as model: 6

Exordium Introduction (to main theme, e.g., by motifs)

Narratio Narration (where applicable)

Propositio Statement of main idea or theme

Confirmatio, Development and analysis of the main theme by means of Confutatio motif-fractionation; refutation of new and contrary themes, motifs, keys, dissonants; confirmation of main idea and key

Peroratio Conclusion

This disposition proves to be very similar to the later Sonata-form-idea so often used in the first movement of the Classic sonata and symphony.

3) Decoratio, the emotional presentation of the ideas, the creation of moods by means of music. ${ }^{7}$ Apart from certain purely musical means like keyrelationships, ${ }^{8}$ intervals, ${ }^{9}$ rhythms, ${ }^{10}$ tempi, ${ }^{11}$ and embellishments, ${ }^{12}$ the different tropes and figures were translated into music where possible, thus creating approximately eighty-two different musical tropes and figures (subdivided into grammatical, pictorial and affective figures) ${ }^{13}$ - see Addendum I.

4) Elocutio, the presentation or recital of music itself. Like rhetoric, emotional involvement is required in music, also the right amount of emphasis, clarity of articulation and meaningful gestures. The latter are to a great extent composed in the music, but the performer has to give expression to these without affectation. ${ }^{14}$

The practice of music as a rhetorical art during the time of Bach drew its essential impulse from the still predominantly theocentric philosophy 
of the early eighteenth century. Music served to instruct the listener (religious instruction in the case of church music, as will be illustrated later), ${ }^{15}$ but relied on a long tradition of musical persuasion.

The psychological and therapeutic use of music was known and practiced in the East and Asia Minor during the second millenium B.C. (e.g., David's music for Saul) and further cultivated in Greece by Pythagoras and others. The Greek Musike did not denote pure music but a complete integration of word, musical sound and dance. ${ }^{16}$ Its influence was such that it was regarded as a powerful ethical force. Plato gave final shape to this concept in his so-called Ethos-doctrine. Certain music and musical instruments were regarded as morally uplifting and were recommended for pedagogical purposes; others, associated with intoxication, orgies and eroticism, were regarded as decadent and prohibited in schools. This Ethos-doctrine was based on the concept of mood (affectus), on Hippocrates' doctrine of the four temperaments and on the prevailing speculative cosmic theories (see below pages 152-54). It was upheld during the medieval period (although music no longer formed an integral part of the dance but showed an increasing independence from the text as it developed polyphonically), but translated into Christian terms. The Church encouraged sacred music and discouraged secular music, especially the rhythmic dances of the jugglers. Renaissance humanism, with its interest in and imitation of nature and human nature (imitatio naturae included the physical and psychic qualities of man), contributed to a renewed study of the influence of music on human nature, but the emphasis shifted: the musical Ethos-doctrine was transformed into the sixteenth century doctrine of moods (Glarean, 1547; Zarlino, 1558) which dominated the musical thinking of the next two centuries. It was a change in emphasis, from the ethical to the more psychological influence of music. ${ }^{17}$ Coupled to this was the Renaissance emphasis on textual clarity, an endeavour to integrate music and words. Textual music of the Musica Reservata (sixteenth-century polyphonic music following Josquin Desprez) endeavoured to match the syntax of the words and simultaneously capture its mood, becoming more rhetorical in essence. ${ }^{18}$

The spiritual climate of the Counter-Reformation, as embodied in the Council of Trent (1545-1563) and the creation of the Order of the Jesuits, further contributed to a rhetorical emphasis in music - at a time when Italy became the new centre of musical development. With its renewed emphasis on the transcendental and on the sinfulness of human nature, the Church actively promoted art which stirred the human conscience and focused on an eternal destiny. The arts became didactic in purpose. This dramatically strengthened the already rhetorical element in six- 
teenth century music. Instead of the Renaissance ideal of balance between text and music, the text dominated music during the Baroque era (ca. 1560-1740); the emotional restraint and the moderate moods displayed in the music of the Renaissance gave way to the most extreme, contrasting moods - hate, love, exultation, depression, etc. - which shocked the listener into attentiveness. ${ }^{19}$ (This change in the concept and purpose of art was later viewed as a decadent phase of the Renaissance and labelled as 'exaggerated,' 'bizarre,' 'extreme,' 'baroque' by the philosophers of the eighteenth-century Enlightenment. ${ }^{20}$ The foundations for a rhetorical concept of music were completed with the development of the monody (accompanied solo song by means of a harmonized, figured bass or basso continuo) around 1600, the accompanied musical recitative (which is an imitation in music of natural speech), ${ }^{21}$ and the new antiphonal style of music of the Gabrielis and the concerto grosso (which created dialogues between vocal or instrumental groups). In Italy rhetoric was applied more intuitively than in Germany where theorists had been discussing and documenting its musical application since the late 1500 's. Music became in theory a musica poetica, ${ }^{22}$ a discipline of rhetoric rather than of mathematics (as it had been in the Ancient and Medieval period, as will be later illustrated). A diagram may illustrate the relation of subjects within the German school system in which Bach was instructed in Lüneburg (see Addendum II): theology forms the pinnacle of this educational pyramid, the subject which gives perspective to all study. Micro- and macrocosmos are seen as the creation of God, the purpose of existence being the glorification of God. All subjects acquire a meaningful relation within God's order. Music becomes instrumental as a discipline of rhetoric to instruct, to communicate, to convert. ${ }^{23}$

With rhetoric as an important approach to musical composition, composers continued and intensified the late-Renaissance trend of creating moods through increasing translation of various tropes and figures of speech into music. Even the structure of a speech (Dispositio) was adopted, leading to the concept of Klang-Rede ('musical speech') in Bach's time with regard to instrumental music. ${ }^{24}$ The various theoretical treatises from the late sixteenth to the middle of the eighteenth century demonstrate an increasing dominance of rhetoric over music. ${ }^{25}$ Analysis of Baroque music itself confirms this trend. This dominance was broken only by eighteenth-century naturalistic philosophy, which seriously challenged a strictly Biblical philosophy and rejected the complex symbolism and transcendentalism of Baroque art (see also Scheibe's critique of Bach, later in this paper). ${ }^{26}$ This resulted in the new classical concept of an 'autonomous music' (Goethe), ${ }^{27}$ music no longer dominated by the text or other extra-musical influences (e.g., Mozart's comments on 
music, especially the opera). ${ }^{28} \mathrm{~A}$ rhetorical concept of music nevertheless lingered on through the early Classics and Beethoven.

Bach's own world view was rooted in the orthodox theology of the Lutheran Church, even if it was a view influenced by pietism and the new currents of rationalism, thus showing discrepancies of which he was unconscious (as Blankenburg and Blume have illustrated). ${ }^{29}$ His Christian philosophy is revealed in various ways. In the tradition of Luther, music always had to be functional. Whether religious or secular it appeared under the heading 'Soli Deo Gloria. ${ }^{30}$ Music thus dedicated to the glory of God did not know the boundaries between sacred and secular; only the text put it into one of these categories. Perhaps for that reason Bach adopted many of his secular cantatas as sacred cantatas and vice versa without regarding this as sacrilege. He wrote in his 'Gründlicher Unterricht des Generalbasses,' 1738: 'Like all music the thorough-bass should have no other aim, end or motivation, than to be to the glory of God and the recreation of the human spirit. If this is not taken into consideration, we do not have real music but an infernal noise. ${ }^{31}$ This Christian world view remains uncompromised by Bach's seemingly contradictory actions, e.g., his ill-temper, his personal clashes with his employers, even his resentment against his unenviable church position in Leipzig, for it transcends the sphere of human weakness. ${ }^{32}$ What Bach meant by 'the recreation of the human spirit' is spelt out clearly in the foreword to his Orgelbüchlein: 'Dem höchsten Gott allein zu Ehren, dem Nächsten, draus sich zu belehren.' It is significant that he used the biblical words 'Nächsten' (fellowman) and 'belehren' ([self]-instruct' by means of the music). The didactic nature of his music, embodied in rhetoric and symbolism, is a direct expression of his Christian philosophy.

The rhetorical quality of Bach's music is not only to be verified by musical analysis but supported by the testimony of his contemporaries. Johann Nikolaus Forkel, the composer's first biographer (1802), who received first-hand information about Bach and his views from Bach's sons, described the composer as the greatest musical poet and the greatest musical speaker in musical history. ${ }^{\prime 33} \mathrm{He}$ reported that Bach regarded music as a complete 'language,' the individual 'voices' (the instrumental or vocal parts in a composition) as 'persons conversing with one another,' listening to one another and trying to contribute to the 'conversation' in a meaningful way. Apart from his training in musical rhetoric at school, Bach became in later years a personal friend of Johann Abraham Birnbaum, professor in Rhetoric at the University of Leipzig. Birnbaum, in mentioning their various discussions on the relationship between the two arts, wrote: 'Bach was so knowledgeable in the sphere of the similarities which exist between the two arts, as well as in the similar 
mode and method of composition, that one not only enjoyed listening to him when he pointed this out in a discussion, but one can only admire the clever application thereof in his compositions. ${ }^{34}$ Equally interesting is the account of one of Bach's pupuls, J.G. Ziegler, in 1746, that Bach instructed him not to play the 'Lieder' so superficially but according to the 'mood of the text.' ${ }^{35}$ The affective, persuasive character of much of his music, whether religious or secular, vocal or instrumental, can be verified through analyses. His St. John's and St. Matthew Passion display this rhetorical, didactic trend throughout, confronting the listener with the religious implications of the events by means of subjective application.

In this regard Bach could draw on a rich heritage of musical composition based on rhetoric, from the Musica Reservata, Monteverdi, Schütz to Buxtehude, Kuhnau and others. This tradition, which is also described in the musical treatises mentioned, is an important aid in the analysis of Bach's music. The mood is generally detectable throughout the text in the tropes and figures, key relationship, metre, rhythms, tempo, intervals and dynamics associated with different moods. In textual works the aspect of 'tone painting' and other descriptive means is of importance. The fact that we deal with relatively objective criteria for analysis of music in Bach's time is also due to the sociological framework within which this music was written. ${ }^{36}$ The composer did not write on the spur of the moment, neither did he display his own changing emotions, but was required (by the court or church) to write music for a specific occasion. The mood was clearly defined by the occasion or the text (something objective with which the composer had to empathize) and he could draw on a general musical vocabulary to achieve this. This is not to suggest that Bach wrote music in a textbook fashion, neither that his music can ever be fully explained and its subtleties captured and described by any analyses.

Two examples from Bach's 'free' (non-textual) organ works might serve to illustrate the rhetorical character of his music: the $G$ Minor Fantasia BWV 542 and the 'Dorian Toccata' BWV 538. ${ }^{37}$

The G Minor Fantasia shows a certain affinity to the St. John's Passion which was composed around the same time. It displays a similar exultation mixed with deep sorrow expressed by the opening chorus of the Passion. It starts with similar repeating exclamations (Exclamatio, Anaphora, Ex. 1), which are converted into an instrumental recitative (a free musical narrative supported by occasional chords; measure $1 \mathrm{ff}$., Ex. 2). 
Ex. 1

St. John's Passion

G Minor Fantasia

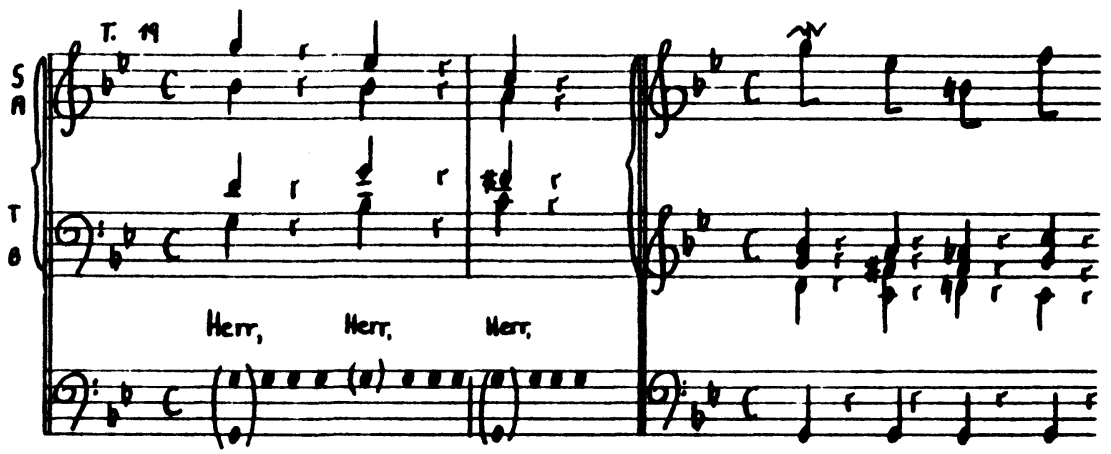

Ex. 2

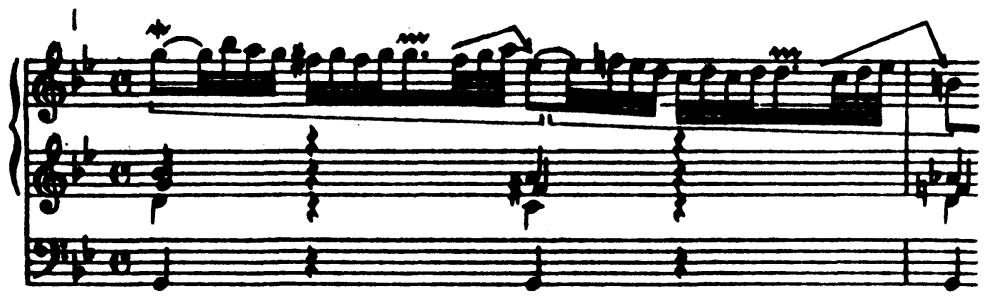

Melodic and harmonic dissonances are employed (Saltus duriusculus, Parrhesia). This is followed by a sequence of repeated and extended motifs (Ex. 3, m. 4-7), an accumulation of ideas and a concluding Seufzer (a descending two-note motif expressing 'sighing,' m. 8-9, Ex. 4).

Ex. 3

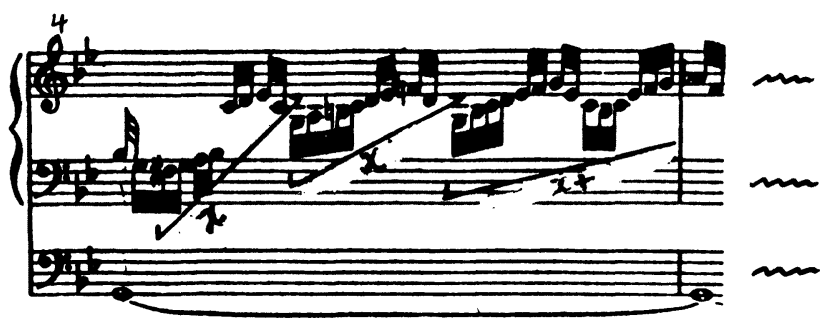




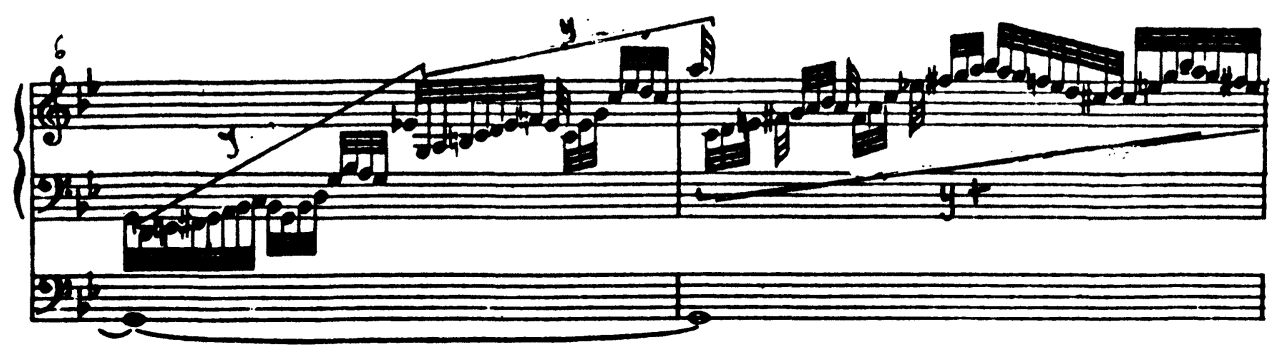

Ex. 4

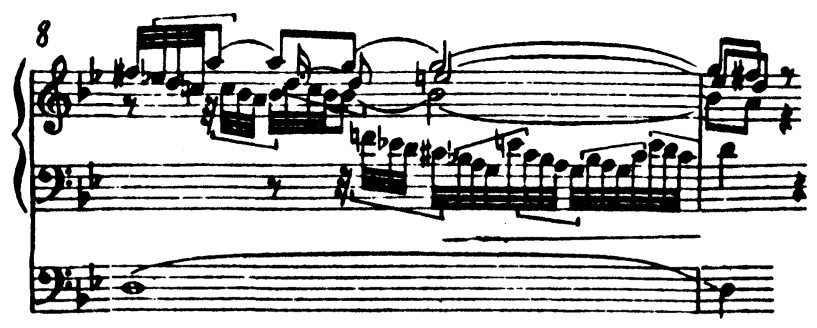

This epic recitative is followed by a contrasting, introverted section in linear counterpoint (horizontal lines of music instead of vertical chords) as a somber 'comment.' The already described 'art of discussion between voice parts' (A, B, C; on a melodiously dissonant bass, D) is cleverly employed (Ex. 5, m. $\left.9^{2}-14^{1}\right)$. The same motifs are used or extended in a discursive way by the various voice parts, and a wealth of figures such as Anaphora, Aposiopesis, Antitheton, Metalepsis, Passus- and Saltus duriusculus is displayed. It ends with a statement (a descending two-note 'sighing motif') similar to measures 8-9 (Epistrophe, Ex. 6, m. 13-14).

Ex. 5

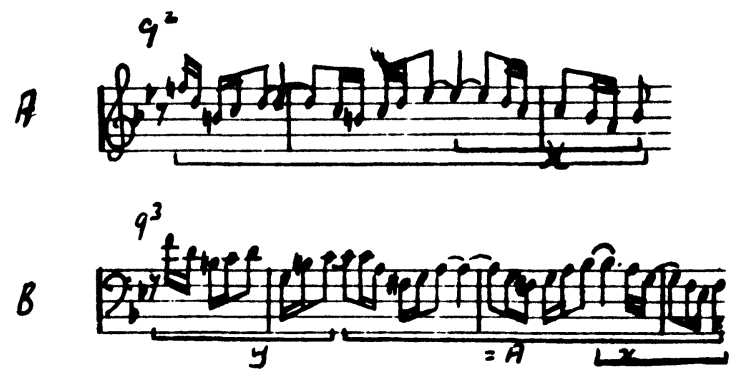



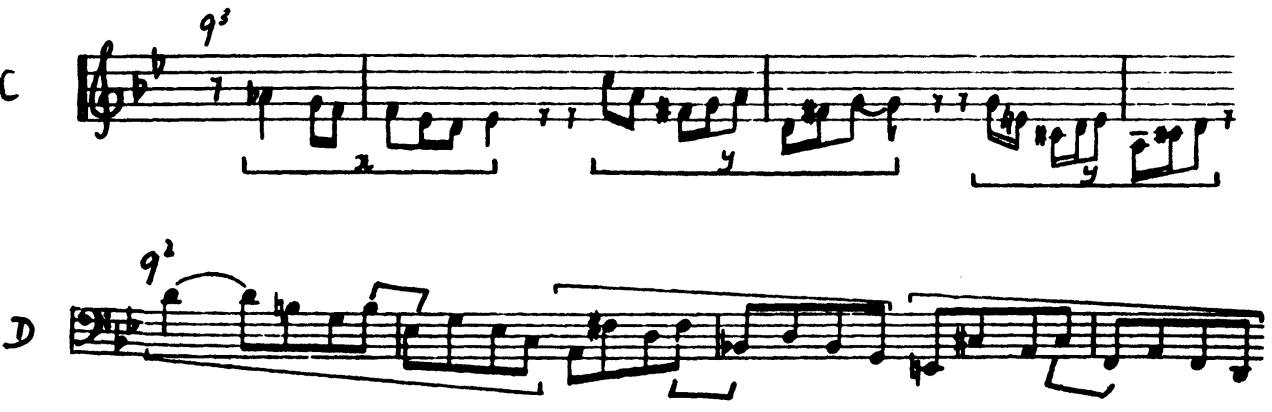

Ex. 6

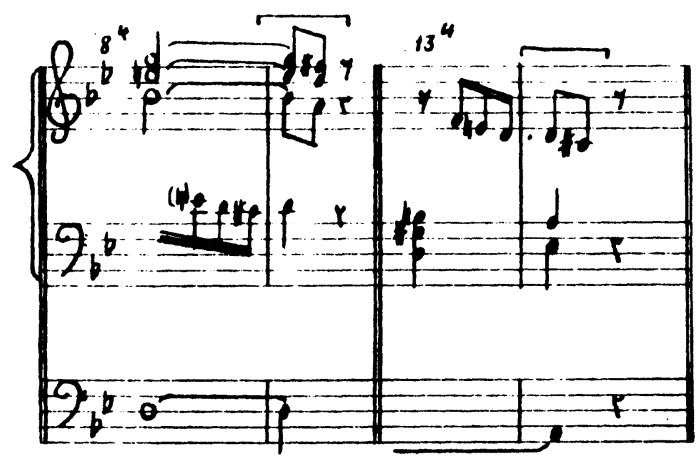

This contrapuntal section is followed by an agitated continuation of the harmonic recitative with a further display of exclamations, dissonant chords, extension and repetition of ideas (Ex. 7, 8), deceptive cadences and climaxes (e.g., Ex. 8, 9). The figures Exclamatio, Parrhesia, Saltus duriusculus, Anaphora, Paronomasia, Ellipsis, and Gradatio predominate.

Ex. 7

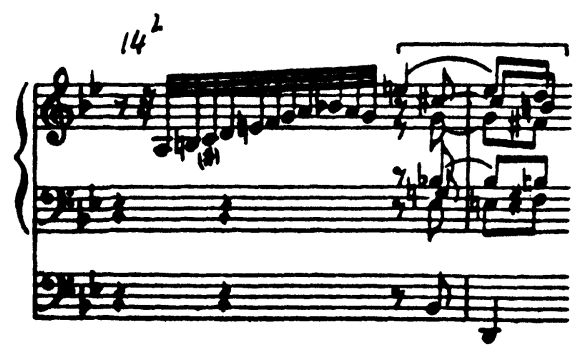


Ex. 8

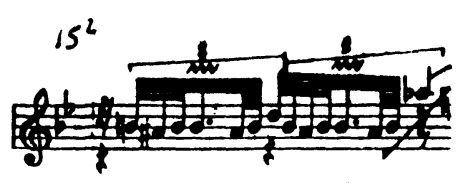

Ex. 9

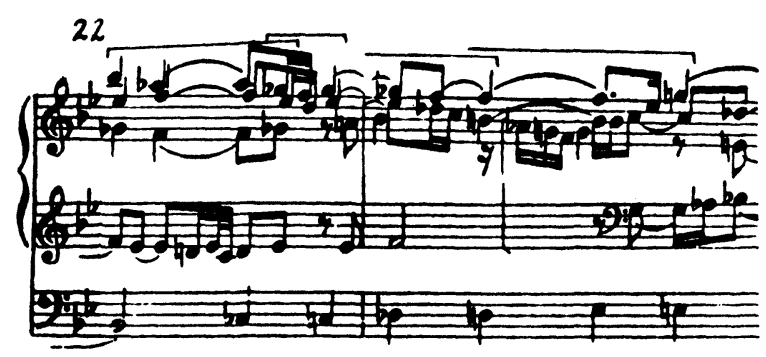

Another contrasting 'discussion' section in counterpoint follows (m. 25-31). After this the highly dramatic recitative is continued, employing the same affective figures as before (e.g., m. 35ff: (1) Gradatio, (ii) Pleonasmus, (iii) Ellipsis, (iv) Congeries, (v) Pathopoiia/Parrhesia, (vi) Suspensio, Dubitatio, Ex. 10).
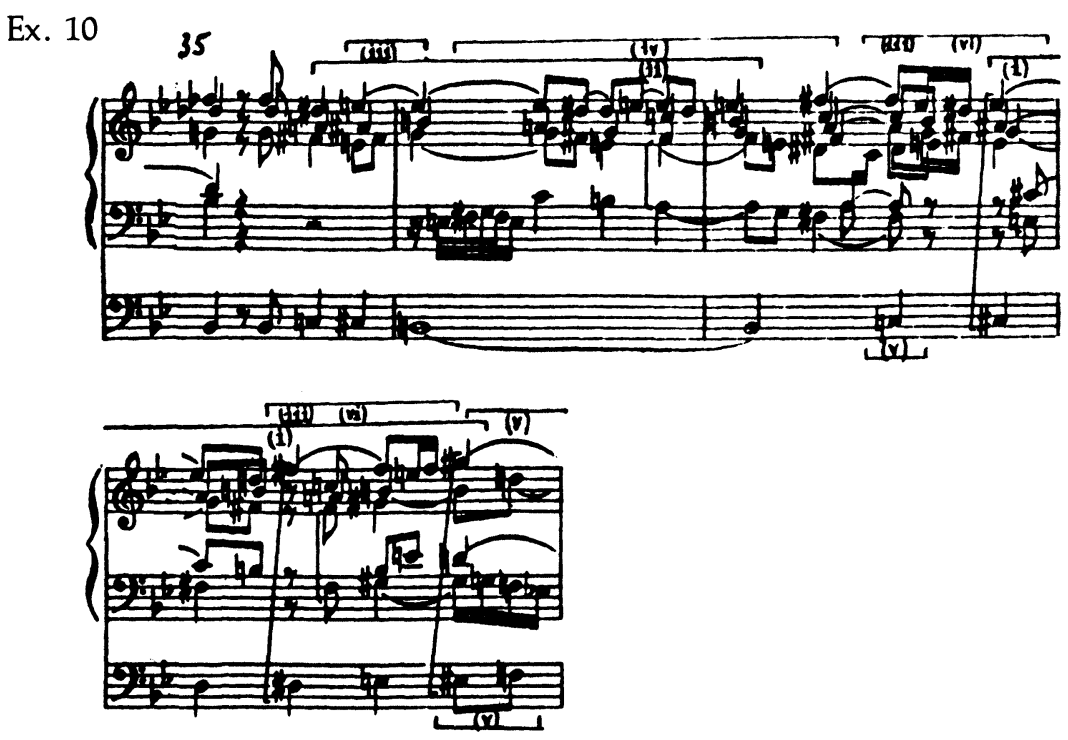
It is only in the final affirmative major chord that the intense, dramatic tension is resolved.

In a completely different vein, rhetoric is used in Bach's 'Dorian Toccata.' This piece employs more abstract, eloquent musical motifs than the highly dramatic, affective ones of the Fantasia just discussed. It is a particularly interesting work: an oratory in dialogue form. The musical 'debate' is brought about by a continuous change between the two manuals, which were minutely indicated by Bach. Organ dialogues were very popular even before Bach, but this dialogue is unique in its logical and dialectical lay-out; it uses both the structure of speech (Dispositio) and a wealth of rhetorical figures. The usual rhetorical arrangement (introduction, statement of main idea, refutation of contrary ideas, analysis and confirmation of main idea, peroration) is followed, but clad in dialogue-style. Instead of the main speaker (A) quoting and refuting opposite views, these views are presented by a second speaker (B), represented through the contrasting registration of the second organ manual.

A starts off by developing the main thesis from a simple motif of alternating notes, $x$ (Anaphora, Paronomasia, Ex. 11).

Ex. 11

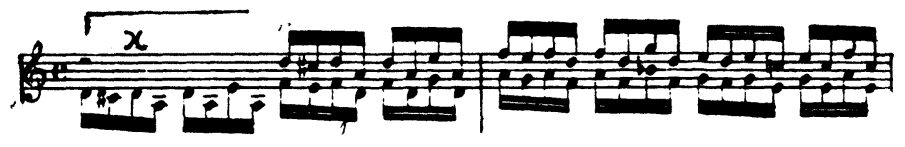

In bar 5 this statement appears in the bass and is reinforced by emphatic chordal accompaniment (y) in the upper voices (Emphasis, m. 5-7, Ex. 12).

Ex. 12

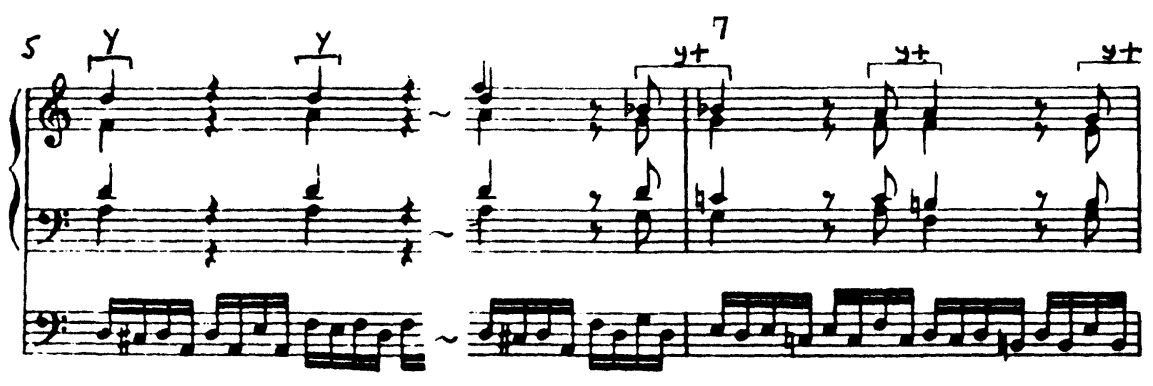


In bar 7 the now emphasized argument is extended $(y+)$ with the addition of a pre-beat chord and the Propositio concluded with a firm cadence in measure 13 (Ex. 13).

Ex. 13
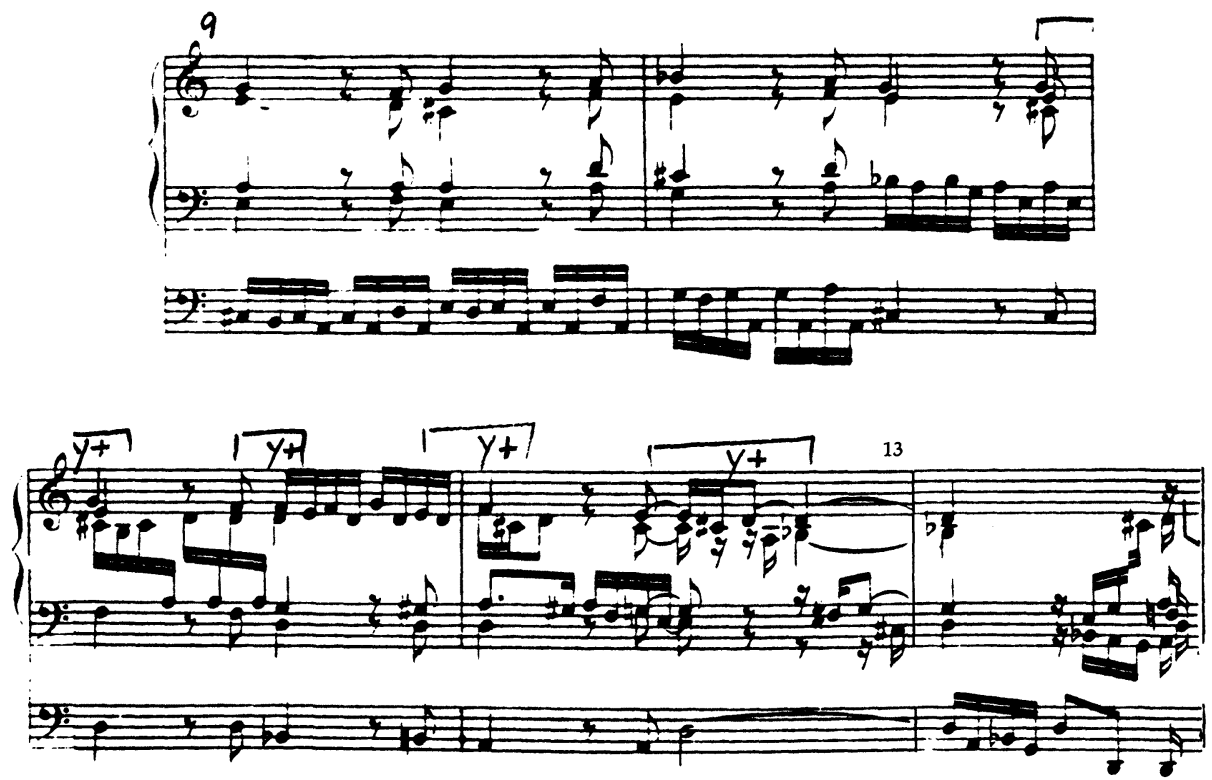

B starts out by quoting the emphasized premise and then inverting it (turning it upside-down with the emphatic chordal motif, $y+$, in the bass) e.g., m. 15, 16 (Ex. 14). Such double counterpoint was seen as an important means of creating antithesis or Antitheton by Bach's contemporary, Mattheson.

Ex. 14

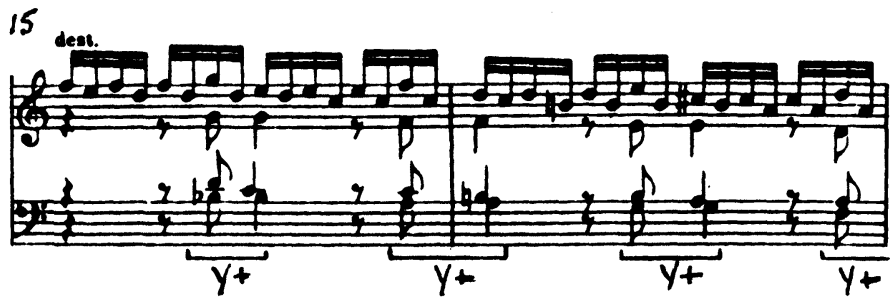


$B$ proceeds by quoting the concluding remarks of $A$ (see $m .10^{4}-13^{3}$, Ex. 13) but extending them (adding another preceding chord to $y$ ), which has the effect of exaggeration, generalization (Paronomasia, Mimesis, Epistrophe, Ex. 15, m. $18^{2}-20^{1}$ ).

Ex. 15

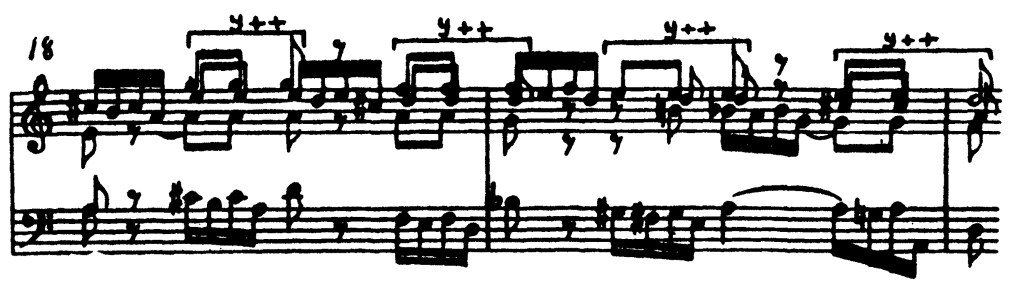

A's reply consists of a parodic quotation and echoing of this exaggeration $(y++)$ alternating between the right and left hand (Anaphora, Mimesis, Dialogismus, m. $20^{1} \mathrm{ff}$. - see Ex. 16).

Ex. 16

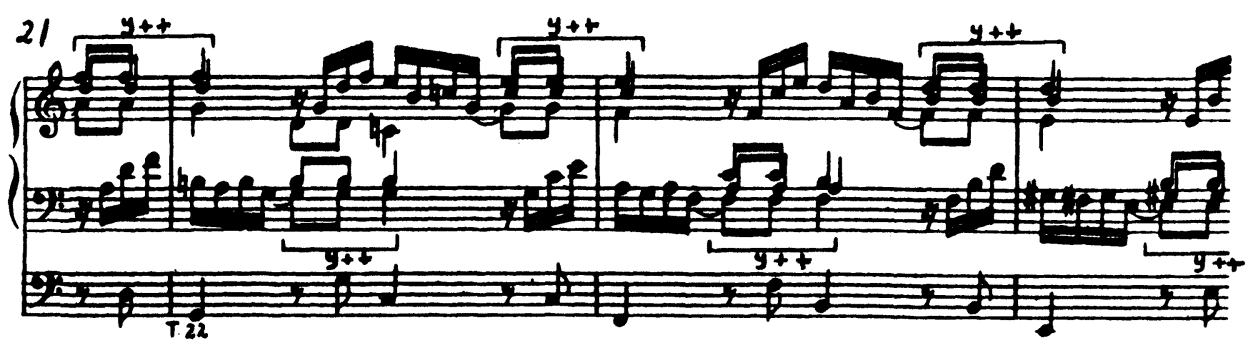

B now picks up A's introductory 'words' (m. 1-4) but in inverted form (inverting the two lines; Antitheton, m. 25-29, Ex. 17). 
Ex. 17
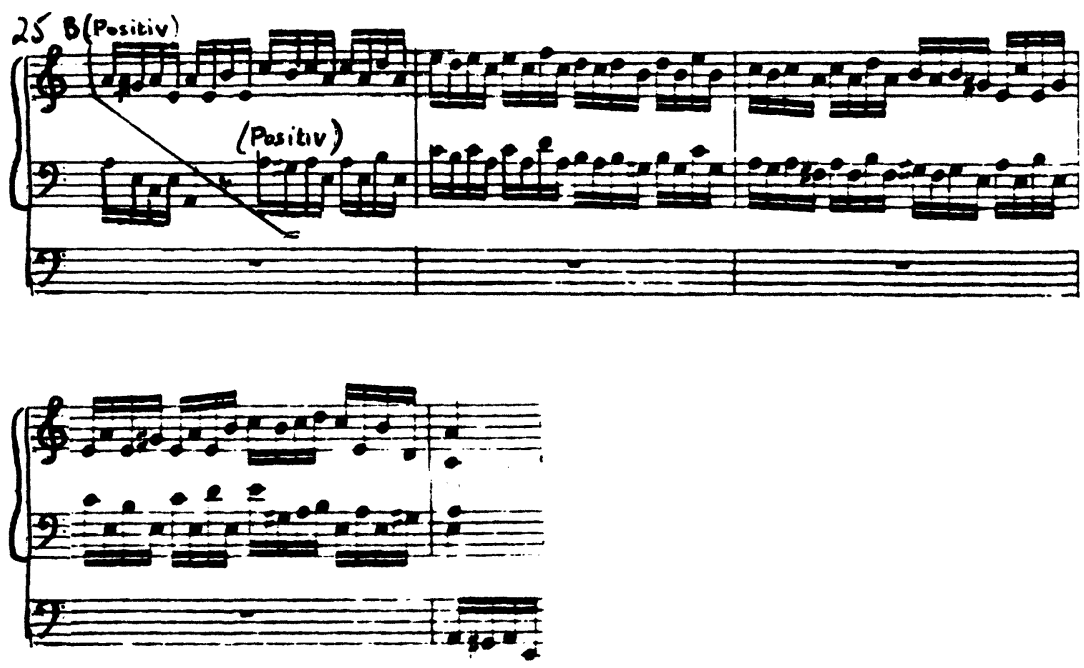

A reaffirms the main thesis by variation and extension (Anaphora, Variatio, Paronomasia), despite opposing interjections from the other who turns the emphatic motif upside down (the ascending motif, A, is changed into a descending one; Mimesis, Antitheton, Exclamatio, m. 29-35, Ex. 18).

Ex. 18

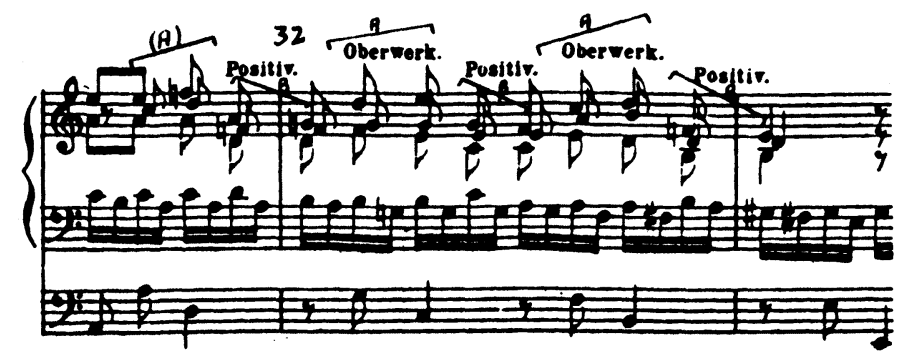

A continues and concludes in a firm cadence (m. 34-371, Ex. 19). 
Ex. 19

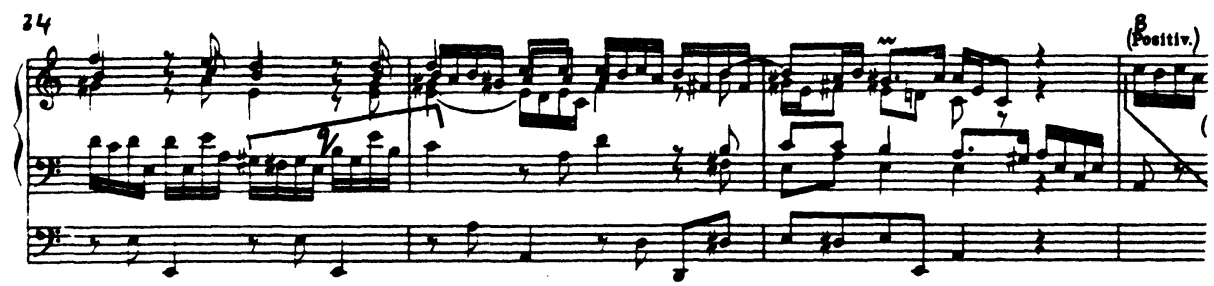

B now quotes a small subsidiary section of the last part (see motif $q, \mathrm{~m}$. 34-35, Ex. 19). This incomplete quotation (Anaphora, bars 37ff.) is immediately countered by A on a lower pitch (Antitheton, Ex. 20). B nevertheless persists and ends with exactly the same emphatic cadence (m. 43, Epistrophe) as the one A used (m. 36, Ex. 21).

Ex. 20

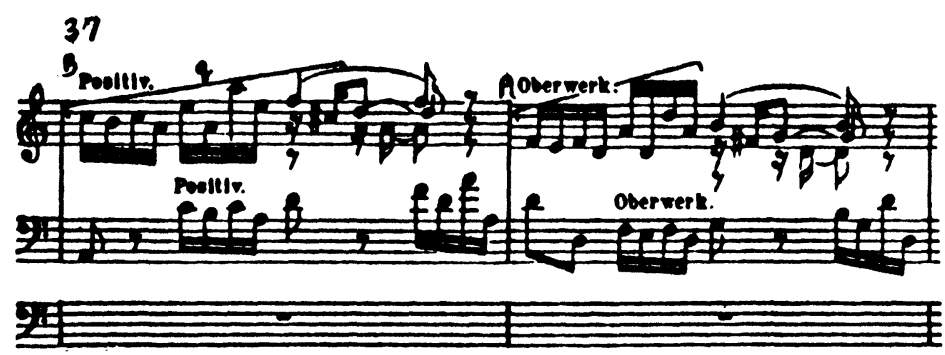

Ex. 21
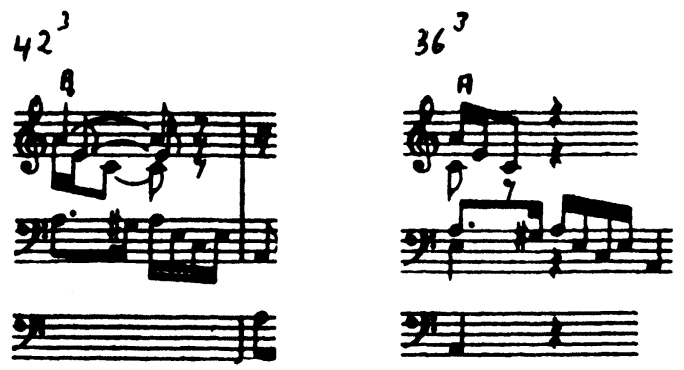

A proceeds to extend the initial proposition (adding three preceding notes to the alternating motif $x$ of m. $1 \mathrm{ff} . ; \mathrm{m} .43$, Ex. 22) despite an interjection by $B$ who repeats it on a lower pitch (Paronomasia, Mimesis, $\mathrm{m}$. 43-47, Ex. 23). 
Ex. 22

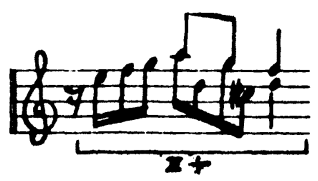

Ex. 23

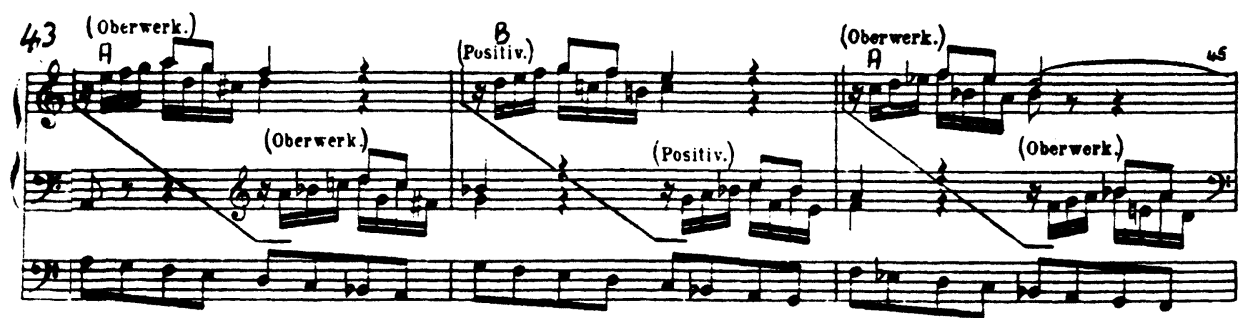

A now strengthens the main proposition by analysis (fractionation of the main idea into smaller motifs of nine notes, then four notes Distributio, Ex. 24), variation and emphasis (Variatio, Emphasis), m. 47-66.

\section{Ex. 24}

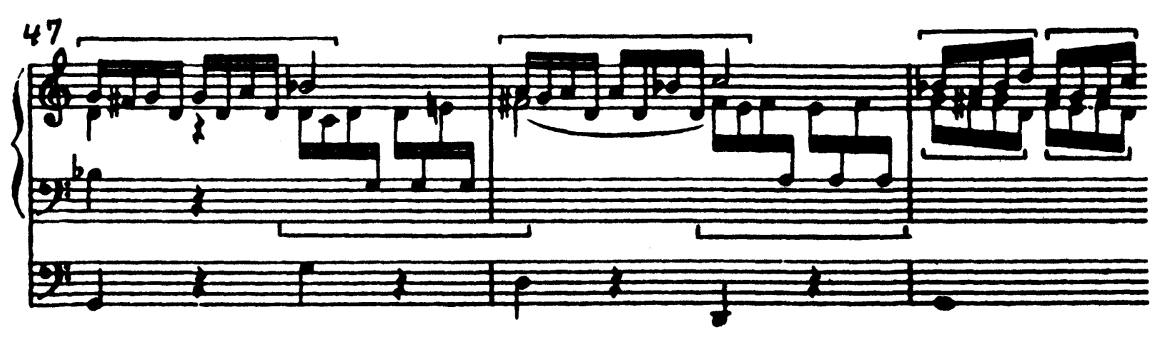

When B's former argument, $q$, is quoted (cf. Ex. 20), B interrupts $A$ and maintains this viewpoint, ending with the same words (cadence) as before (Antitheton, Emphasis, Epistrophe, m. 66-73).

A repeats the extended thesis, but is directly confronted by B with repetitions of these motifs on a different pitch (m. $76^{3} \mathrm{ff} .$, Ex. 25) and then even interrupted before completion (m. 78). At this point $A$ and $B$ 
speak simultaneously, repeating their 'words.' This heated debate leads to an accumulation of the same viewpoints (Congeries, $\mathrm{m}$. $78 \mathrm{ff}$.) in an ascending sequence, leading to the climax (Gradatio, Ex. 26), in which $A$ simply 'talks B down' (Pleonasmus, m. 81, Ex. 27).

Ex. 25

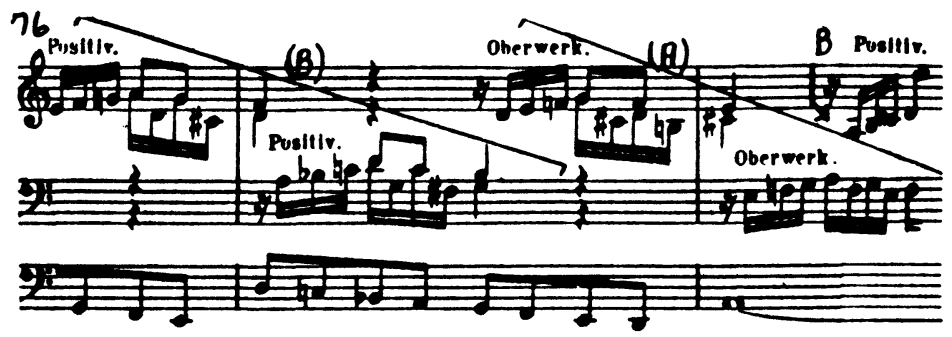

Ex. 26

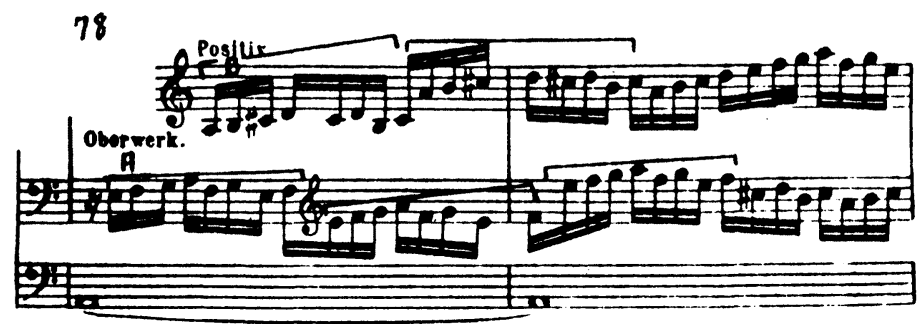

Ex. 27

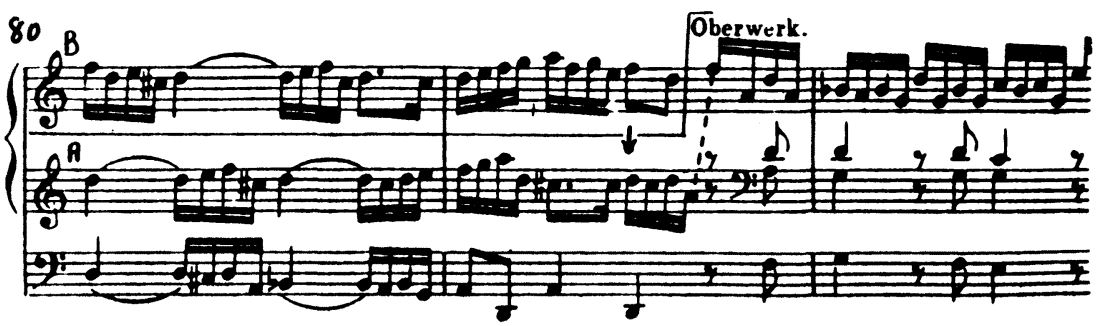

A follows this up by a spirited confirmation of the main thesis with new extensions and analyses (fractionation of motifs), reaching a victorious climax (m. $90 \mathrm{ff}$., Ex. 28) symbolized by a change from D minor to D ma- 
jor $\left(\mathrm{m} .94^{3}\right)$, the key associated by Mattheson with victory, jubilation and aggressiveness.

Ex. 28
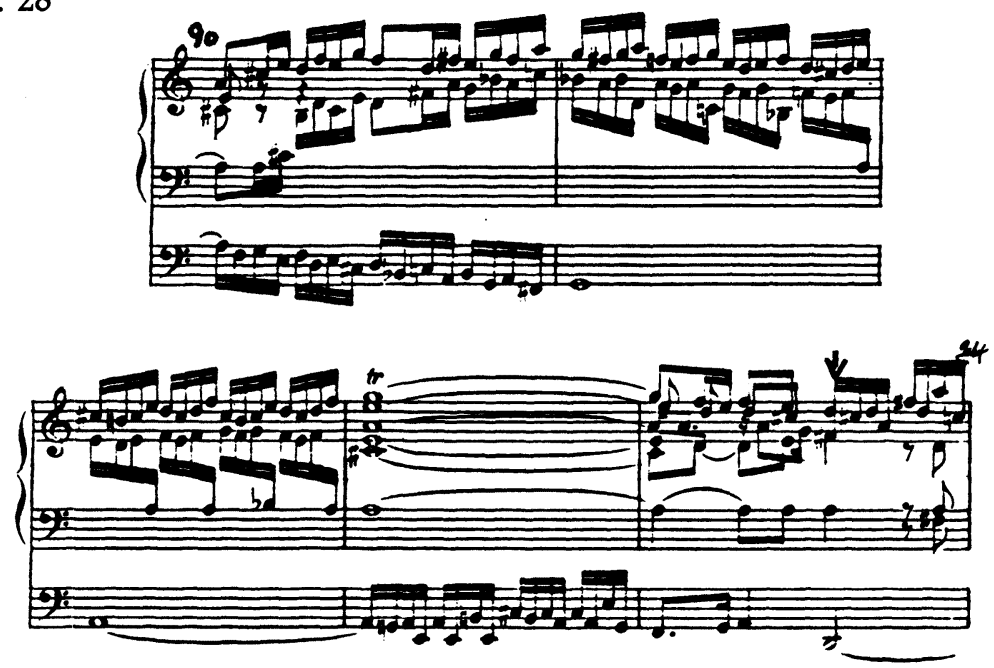

Assured of success, A concludes with strong, emphatic repetitions of the initial alternating motif, $x$, extended by an ascending, leaping interval (Congeries, Emphasis, Ex. 29).

Ex. 29
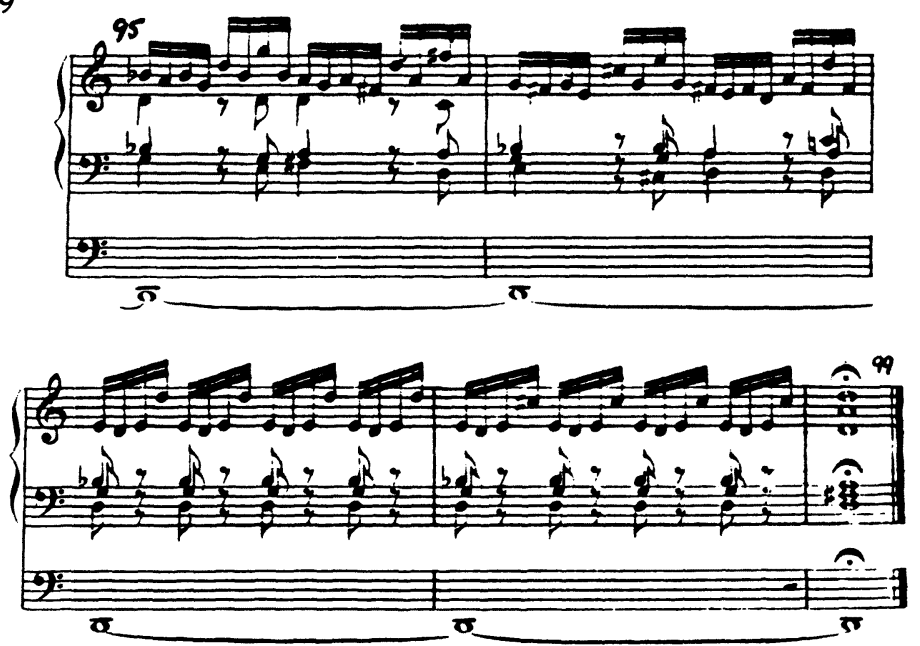
Bach's 'Dorian Toccata' and the $G$ minor Fantasia are only two illustrations of the idea of a purely musical, instrumental Klang-Rede in the lateBaroque. As Mattheson wrote (1722): 'Although instrumental works do not employ actual words, nevertheless even the most free and independent works ('Concerten') should contain an expression, an intelligent content, so that they always have something to say and also speak words. ${ }^{\prime 38}$

The idea, sometimes encountered, that Bach's organ music is essentially unemotional, abstract, 'pure music,' music based on 'pure musical form and development' to be played without affect, fails to recognize the philosophical and compositional concepts from which these works originated. But it must be kept in mind that the emotion called for in these works differs from the Storm and Stress of Romantic music. It calls for careful analysis and recognition of the inherent mood of the work. This mood does not change continually as in Romantic music, but remains (apart from subtle shadings) constant for a prelude, fantasia, fugue, choral prelude unless a change in style, tempo, dynamics, etc., occurs. An affective involvement of the player is required to project the mood to the listener.

\section{Other symbols in Bach's Organ Music}

There are other communication symbols in Bach's music which transcend the dialectical, logical, ethical and psychic levels of rhetoric. They occur especially in his textual organ music, i.e., chorale preludes (hymn arrangements). The employment of these symbols by Bach is equally rooted in his Christian world view and can equally be traced back to concepts dating from the pre-Christian era. They range from fairly direct symbols also employed in rhetoric, such as allegory and imitation, to the more abstract or esoteric ones of emblems, semantics of number and number cabalistics. ${ }^{39}$

1. Allegory, comprising an association of extra-musical contents with musical signs, can be understood by the hearer mainly from the 'sensuous' effect: 'Fall,' 'plunge,' but also 'abyss,' 'sin,' 'damnation' by descending voices, stepwise or by leaps; 'light' and 'dark,' 'heaven' and 'hell' by contrasting high and low registers; 'length,' 'effort,' 'hardship' by sustained rhythms in contrast to the quick rhythms for 'hurry, 'flying,' 'rapture.' Descriptive allegory can also be classified under the rhetorical 'hypotyposis'-figure and other figures like Antitheton, 
Passus- and Saltus duriusculus, Ellipsis, Anabasis, Katabasis, Circulatio.

2. Imitation is the direct copying in music of sounds and noises (chime of bells, birdsong, storm, knocking, etc.).

3. Emblematical, visual symbols are musical signs which translate wordcontent into tonal figures in a manner which cannot simply be understood from the sensuous effect of those tonal figures, but must be consciously 'known' (or 'seen' in notation); for example: the countless use of the raised tone sign (sharp) in Bach's Kreuzstabkantata (the Christian bearing of the cross'), as the German word for sharp is 'Kreuz' (in English 'cross' and 'sharp' would never be associated); the use of the note $G$ (or Sol in medieval times) for the Latin word 'sol' ('sun'); 'nox' ('night'), represented by blackened notes, etc.

4. Semantics of number consists in the translation of ideas into musical signs by means of numerical symbols, e.g., seven for Creator and creation, beginning and end; twelve for Church, disciples, congregation; three for Trinity, perfection, the transcendental, etc.

5. Number cabalistics consists of the translation of alphabetical letters into numbers, thus allowing composers to write words or their own names in music by means of the number of notes used in a theme, motif, or entire work or the number of bars used (e.g., Bach $=14$, J.S. Bach $=41$.

This tradition of visual, mathematical 'musical symbolism' can be traced back to Antiquity. ${ }^{40}$ In the ancient Chinese, Babylonian and Egyptian cultures a cosmology of music was developed which was rooted in religious concepts and in the symbolism of number. Musical intervals were expressed in terms of numbers, e.g., the octave being 1:2, the fifth $2: 3$, the fourth $3: 4$, etc. These numbers were derived not only from the division of an open lute string in the ratio 1:2, 2:3, 3:4, but they also correspond with the numbers of the natural harmonics ('upper partial tones') obtained by 'overblowing' a wind instrument. In a more speculative way distances between celestial bodies and the relation between the human soul and body were linked together, laying the foundation for a cosmology of music based on number. Consequently, certain intervals influence the human soul, but so do celestial bodies. Stars and planets, moving in a harmonious geometric relation to one another, also create a celestial harmony which is inaudible to the restricted human ear. This concept of a musica mundana (celestial harmony) was further developed by Pythagoras and the Greek theoreticians as a counterpart to the equal- 
ly speculative musica humana (the 'harmony between soul and body') and the musica instrumentalis (audible music, 'music' in the sense we use the term). The audible music thus became a microcosmic image of a divine creation, a link between this visible world and the transcendental, powerful as an ethical force to uplift or corrupt man by means of the concept of musica humana. This speculative, mathematical basis of music became the rather vague motivation for Plato's Ethos-doctrine. Numbers acquired a magic, symbolic meaning not to be tampered with. Pythagoras tried to calculate all intervals by means of the numbers one to four, since $1+2+3+4=10$, and ten is a perfect number. This might also explain the initial use of only four strings on the Greek lyre and of four-note scales (tetrachords) as basic units. An increase in the number of strings on a musical instrument was regarded as sacrilege. This symbolism of numbers existed also in the ancient Jewish culture and religion; the idea of the creation as something harmonious which sings and praises the Lord partly accounts for the wealth of symbolism in the Old Testament.

With the Christian era these ancient speculative concepts were adopted and explained in Christian terms in the Alexandrian theology. As in Greece and Rome, music remained a discipline of mathematics in the medieval system of the seven Artes liberales (the mathematical sciences constituting the Quadrivium being Geometry, Arithmetic, Astronomy and Music; the linguistic subjects constituting the Trivium being Grammar, Dialectics and Rhetoric). In Biblical symbolism the number three is seen as perfect; with the introduction of rhythmic modes in the twelfth century only triple metre and threefold subdivisions of note values were used. When binary rhythm is introduced in the fourteenth century, it is seen as part of the secular tendencies of the Ars Nova and is censured by the church, since the number two is 'imperfect,' hence of a 'wordly' nature. The use of semantics and other forms of musical symbolism is retained in the Renaissance in the form of riddle canons and other manneristic devices (e.g., Ockeghem), and is combined with sound imitation (the new rationalistic imitatio naturae) and the creation of moods (especially following Josquin in the early sixteenth century). ${ }^{41}$

When music became a discipline of rhetoric (part of the linguistic sciences) during the Baroque, the art of musical symbolism, semantics, imitation and a cabalistics of number did not die out; it received new stimulus from the renewed emphasis in the arts on the metaphysical and the transcendental. The seventeenth century theoreticians (such as Mersenne $^{42}$ and Kircher ${ }^{43}$ ), therefore, still conveyed the ancient speculative concept of a musical cosmology (Musica mundana), of a celestial, inaudible harmony based on number. Similarly, composers and 
theoreticians display a profound knowledge of the traditional symbolic arts. In the introductions to his compositions and an unpublished treatise Bach stressed the functionalism of music in terms of a deeper symbolism. According to Blume, music that reflects in its number and rule the divine world order, that is based on the harmonia aeterna and laws of nature, is for Bach real functional music which deserves to exist. In his 'Instruction in Figured Bass' Bach describes musical harmony built on the Generalbass in terms of such religious symbolism (see above). Studies of various treatises by contemporaries of Bach like Werckmeister ${ }^{44}$ have revealed a musical practice still actively employing musical symbolism. Analyses of Bach's textual music, and more recently of his purely instrumental compositions, have indicated a wealth of latent symbolism, semantics and cabalistics of number, allegory and imitation.

In his Clavierübung, 3rd Part, consisting of various organ choral preludes based on hymns from the regular Lutheran Communion service, Bach uses as framework a 'Trinitarian' Prelude and Fugue (the 'St. Anne's,' BWV 552): the majestic Prelude is based on three themes, the Fugue on three which are cleverly interlocked. In the Credo of the $B$ minor Mass Bach uses the word Credo $7 \times 7=49$ times, in unum Deum 7 $x 12=84$ times; at the end of the fugue Patrem omnipotentem Bach significantly adds the number of bars (84). ${ }^{45} \mathrm{He}$ not only wrote his own name by using the German note names B-A-C-H (B flat-A-C-B) but, in the tradition of Werckmeister, Picander and J.J. Schmidt, did so by means of number cabalistics (as Friedrich Smend ${ }^{46}$ has shown by extensive analysis and research). In the Orgelbüchlein a combination of symbols, allegory, imitation and semantics of number is used: allegory in the form of associative motifs, e.g., 'rocking-,' 'fall-' and 'damnation-,' 'ascension-' and 'descension-' motifs; imitation by means of 'knocking-,' 'trembling-,' 'trumpet-' motifs; semantics of number (e.g., twelve to symbolize the Old Year in Das alte Jahr vergangen ist); symbolism, e.g., strict imitation or canon as symbol of 'following,' 'obedience,' bondage,' 'captivity.'

Significant for an understanding of Bach's music is that, no matter how spontaneous or inspired it sounds, behind the seemingly musical construction and the psychological aspect of mood creation, there exists a structure of a more abstract nature. The two levels of communication, the affective and more abstract symbolism, usually complement one another. A rendering of his music should therefore not be restricted to a purely emotional level, or become a purely abstract reflection of a rational art. It should recognize this kind of Baroque Gesamtkunstwerk (total, integrated work of art), which relied on century-old concepts, and which is rooted in Bach's musical philosophy. That Bach was attacked 
during the late 1730's by the younger Johann Adolph Scheibe ${ }^{47}$ a fervent supporter of the new purely naturalistic aesthetics of the Enlightenment, is evidence of Bach's traditional ideas. In the spirit of the new generation he denounced Bach's symbolism and metaphysical emphasis and urged him to follow the new naturalistic ideal, to express his own natural emotions in an uncomplicated musical style, instead of reflecting a speculative, transcendental world or creating a prescribed mood by means of complex music.

Two short examples of Easter music from the Orgelbüchlein may serve to illustrate the combination of mood and more abstract symbolism in his chorale preludes:

\section{Erschienen ist der herrliche Tag}

The glorious day has come, for which no man can be joyful enough: Christ, our Lord triumphs today and carries with him all his enemies in captivity. Alleluia!' The metaphor is the one used by the apostle Paul to portray Christ's triumph over death and damnation. The enemy, in accordance with Roman custom, is tied to the victor's chariot for a triumphant procession through the city. Bach unites symbolism and mood very effectively. As symbol he uses a canon (strict voice imitation) between the upper voice and the bass. In effect the bass is 'tied' to the upper voice and 'dragged' along at a fixed distance. The metaphor of the 'captive' enemy becomes completely clear in this context. Simultaneously the basic mood of triumph is created by the use of a pompous, anapestic rhythm-motif (short-short-long) in the central voice parts and the triumphant climax in the change to $D$ major (tierce de Picardie) in the final cadence (Ex. 30).

Ex. 30

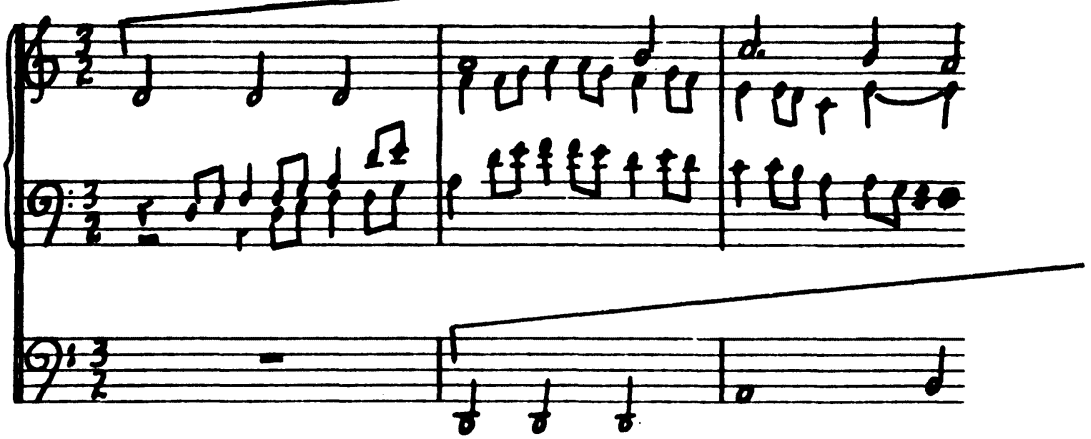


This example clearly illustrates the difference in communication level between direct and indirect symbols. While the triumphant mood of the music is directly experienced by the listener, the symbol of 'capitivity' requires familiarity with and decoding within the Lutheran theology. The same applies to the next example.

\section{Jesus, Christus, unser Heiland}

'Jesus Christ, our Redeemer, who has triumphed over death, is risen and has taken death into capitivity. Alleluia!' The celebrative mood is captured by the subdivision of the 4/4- into 12/8-metre by means of triplets. A change from basic binary to triple note values was often used before Bach (by Schütz, e.g.) to capture, portray and symbolize something of the blissfulness and joy of the heavenly, ethereal and perfect. Apart from the basic mood and the use of semantics of number, the resurrection itself is portrayed allegorically by a dynamically ascending, leaping interval. This resurrection-motif of two ascending notes occurs in all the voice parts and in various intervals ranging from the second to the full octave. It is most effective because of the emphasis on the second, 'off-beat' note which is tied to the next group of notes (Ex. 31).

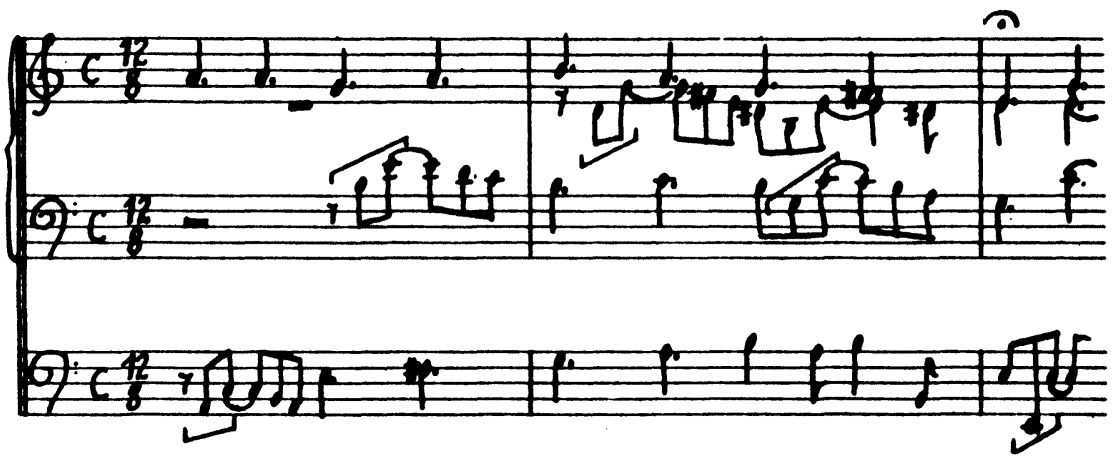

In conclusion, recognition of the rhetorical and other symbolic aspects of Bach's organ music is not only a matter of importance to the music 
historian. For the listener it means a keener perception of Bach's musical idiom as well as added enjoyment; for the performer, an appropriately rational-affective rendering with its implications for articulation, ornamentation, choice of timbre, dynamics, tempo and agogics.

\section{JACOBUS KLOPPERS}

The King's College, Edmonton

\section{Addendum I}

Some of the approximately 82 different musical tropes and figures developed from the sixteenth to eighteenth centuries:

Grammatical and pictorial figures:

Anabasis:

Circulatio:

Katabasis:

Hypotyposis:

Passus duriusculus:

Saltus duriusculus:

Affective figures:

Anaphora (Repetition)
Ascending scale (e.g., 'ascension of Christ')

Circulating movement (e.g., revolving movement, 'encirclement')

Descending scale (e.g., 'descent,' 'depression,' 'humiliation')

Tone painting (imitation in music of sounds, movements, gestures of specific qualities of an object)

A dissonant melodic progression (e.g., the tritone)

Dissonant interval (e.g., diminished and augmented intervals)

and other kinds of repetition:

Extended (Paronomasia), emphatic (Epanalepsis), varied (Variatio), divergent (Polyptoton), with similar phrase endings (Epistrophe)

Antitheton:

Aposiopesis:

Congeries:

Antithesis (any musical contrast, e.g., inversion of a motif)

General pause, silence (to depict death, sighing, deep sorrow, awe)

Accumulation of the same idea 
Dialogismus: Musical dialogue (e.g., the antiphonal style, concerto grosso, organ dialogues)

Distributio:

Dubitatio:

Ellipsis:

Emphasis:

Exclamatio:

Gradatio, Climax:

Hyperbaton:

Hyperbol:

Interrogatio:

Metalepsis:

Mimesis:

Parrhesia:

Pleonasmus:

Polysyndeton:

Tmesis:
'Analysis' of the main idea, the fractionation of a theme into small motifs

Expression of doubt and uncertainty (e.g., dubious modulation, sudden standstill)

Ellipse, a 'wrong conclusion' (illogical progression, disruption of an idea, deceptive cadence)

Emphasis (accent, an emphatic chord)

Musical exclamation, e.g., by means of a note or chord that is not sustained but broken off

Musical climax, e.g., by parallel ascending voices

'Wrong order' of notes, 'distortion' of a theme or motif because of excitement

Hyperbole, exaggeration in music

Question or rhetorical question (e.g., an ascending appogiatura in a half-cadence)

Premature conclusion (premature entry of a voice or motif)

Ridicule in music (e.g., repetition in a dialogue at a different pitch level)

Harsh expression of rage, conflict, anguish, pain by means of dissonants and dissonant chord-progressions

A redundant repetition of an idea because of emotional involvement

Postponement of the final cadence

Disruption of a melodic line by inserting rests (as an expression of deep sorrow and sighing) 


\section{Addendum II}

The educational system in Germany during the Baroque period:

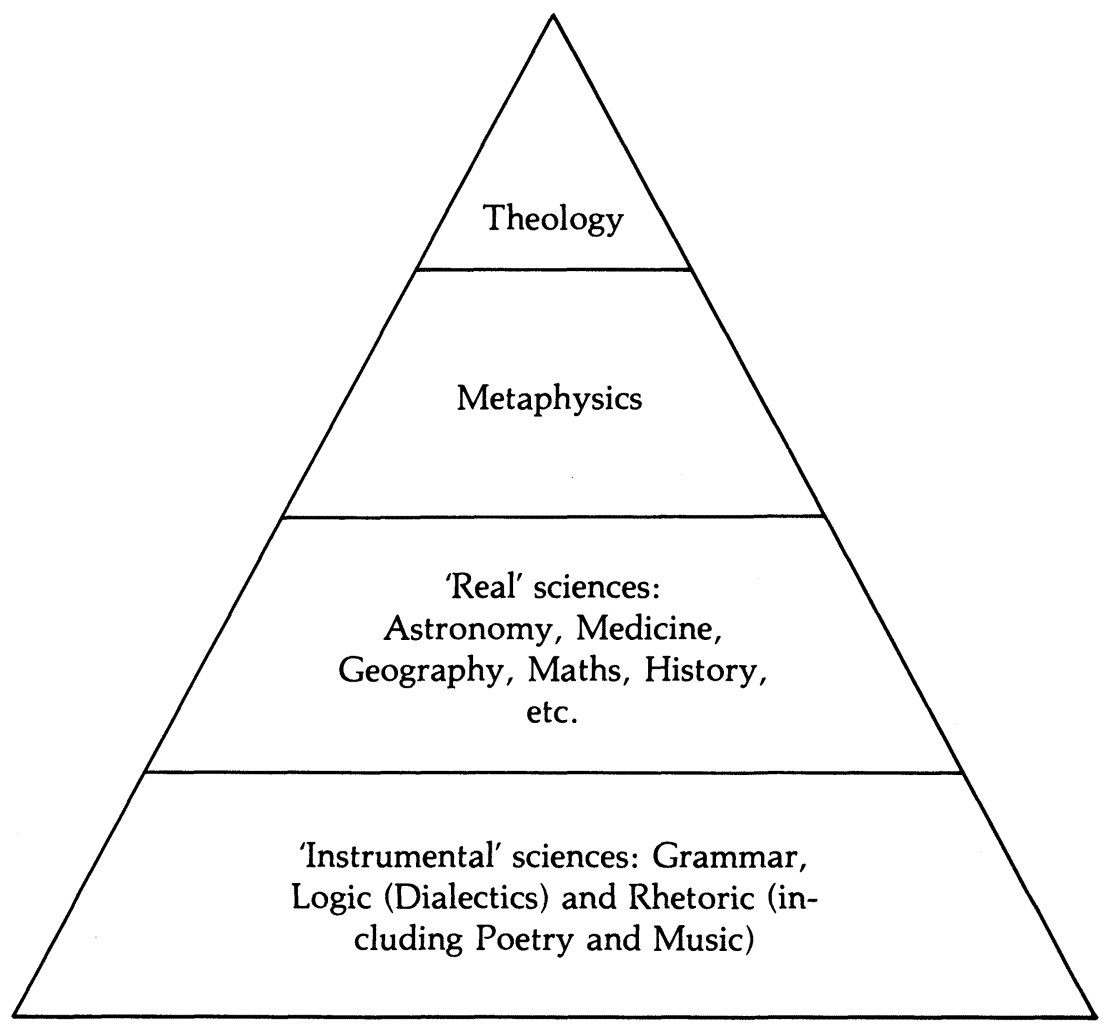


Notes

1 Research on musical rhetoric and symbolism was pioneered by German musicologist Arnold Schering at the beginning of this century. What had been earlier considered as Bach's unique musical vocabulary for conveying textual ideas (by, e.g., Albert Schweitzer), proved to be a 'vocabulary' of musical rhetoric widely used since the sixteenth century, and of an ancient musical symbolism still alive in Bach's time. More than 200 treatises from the sixteenth to the eighteenth century provided a theoretical basis for subsequent musical analyses by Schering and others. A complete list of published research on this subject is beyond the scope of this paper. For Bach, cf., e.g., Albert Schweitzer, Johann Sebastian Bach (Leipzig, 1908; reprint Wiesbaden: Breitkopf und Härtel, 1960); Rudolf Wustmann, 'Tonartensymbolik zu Bachs Zeit,' in Bach-Jahrbuch (1911), pp. 60 ff.; Arnold Schering, 'Die Lehre von den musikalischen Figuren im 17. und 18. Jahrhundert,' in Kirchenmusikalisches Handbuch (1908), pp. 108ff.; also, 'Bach und das Symbol,' in Bach Jahrbuch (1937), pp. 83-95; Hans-Heinrich Unger, Die Beziehungen zwischen Musik und Rhetorik im 16.-18. Jahrhundert (Würzburg: Konrad Triltsch, 1941; reprint Hildesheim: George Olms, 1969); Friedrich Blume, 'J.S. Bach,' in Die Musik in Geschichte und Gegenwart, vol. 1 (1949-51), pp. 962ff.; Arnold Schmitz, Die Bildlichkeit der wortgebundenen Musik J.S. Bachs (Mainz: B. Schott, 1950); Jacobus Kloppers, Die Interpretation und Wiedergabe der Orgelwerke Bachs: Ein Beitrag zur Bestimmung von Stilgerechten Prinzipien (Ph.D. Dissertation, J.W. Goethe University, Frankfurt/Main, 1965; distributed by Bärenreiter Antiquariat, Kassel); Timothy Albrecht, Musical Rhetoric in Selected Organ Works of Johann Sebastian Bach (Dissertation, University of Rochester, 1978); Warren Kirkendale, 'Ciceronians versus Aristotelians on the Ricercar as Exordium, from Bembo to Bach,' Journal of the American Musicological Society, 32 (1979), 1-44; Ursula Kirkendale, The Source for Bach's "Musical Offering": The "Institutio Oratoria" of Quintilian,' Journal of the American Musicological Society, 33 (1980), 88-141.

2 Cf. Heinrich Lausberg, Handbuch der literarischen Rhetorik: Eine Grundlegung der Literaturwissenschaft (Munich: M. Hueber, 1960), pp. 140ff.; Edward P.J. Corbett, Classical Rhetoric for the Modern Student (New York: Oxford University Press, 1971), pp. 3ff.; Unger, op. cit., p. 3.

3 Ibid., pp. 17-20.

4 Athanasius Kircher, Musurgia Universalis (Rome: Francesco Corbelletti, 1650; reprint Hildesheim: George Olms, 1970), vol. 1, liber 5, cap. 19.

5 Johann Mattheson, Der vollkommene Capellmeister (Hamburg: Christian Herold, 1739), pp. 121-32.

6 Ibid., pp. 235-36.

7 Cf. Unger, pp. 99-109; Kloppers, pp. 126-75.

8 Cf. Johann Mattheson, Das Neu-Eröffnete Orchestre (Hamburg: Schillers Erben, 1713), pp. 232-51; also Rita K. Steblin, Key Characteristics in the eighteenth and early nineteenth centuries: $A$ historical approach (Thesis, University of Illinois at Urbana-Champaign, 1981), pp. 63-86. 
9 Johann Kirnberger, Die Kunst des reinen Satzes (Berlin and Königsberg: Decker \& Hartung, 1774-1779), Vol. 2, pp. 102-104; Johann Joachim Quantz, Versuch einer Anweisung die Flute traversière zu Spielen (Berlin, 1752; reprint Kassel:

Barenreiter, 1953), chapter $11 \S 16$.

10 Kirnberger, vol. 2, pp. 105ff.; Quantz, chapter $11 \S 16$; Mattheson, Capellmeister, pp. 160-70.

11 Kirnberger, p. 106; Friedrich W. Marpurg, Anleitung zum Clavierspielen (Berlin: Haude und Spener, 1765), p. 16.

12 Friedrich W. Marpurg, Historisch-Kritische Beyträge zur Aufnahme der Musik (Berlin: Schützens Witwe, 1757), p. 120.

13 Cf. Unger, pp. 63-96 for a complete list and description of these sources; also Arnold Schmitz, 'Figuren, musikalisch-rhetorische,' in Die Musik in Geschichte und Gegenwart, ed. Friedrich Blume, 4 (Kassel: Bärenreiter, 1955), 176-83.

14 Cf. Unger, pp. 112-18.

15 Cf. Friedrich Blume, Renaissance and Baroque Music: A Comprehensive Survey (translation of two of Blume's German articles by M.D. Herter Norton; New York: W.W. Norton, 1967), pp. 89-92.

16 Joseph Müller-Blattau, Das Verhältnis von Wort und Ton in der Geschichte der Musik (Stuttgart: Metzler, 1952), p. 12.

17 Kurt Huber, Musikästhetik (Ettal: Buch-Kunstverlag, 1954), pp. 45-47; Unger, p. 24.

18 Cf. also Müller-Blattau, p. 23.

19 Cf. Blume, Renaissance and Baroque Music, pp. 90-93.

20 Cf. ibid., p. 89.

21 Cf. also Egert Pöhlmann, 'Antikenverständnis und Antikenmissverständnis in der Operntheorie der Florentiner Camerata,' Die Musikforschung (1969), pp. 5-13.

22 Cf. Kurt Gudewill, 'Heinrich Schütz,' Die Musik in Geschichte und Gegenwart, ed. Friedrich Blume, 12 (Kassel: Bärenreiter, 1965), pp. 213-14; H.H. Eggebrecht, Heinrich Schütz: Musicus Poeticus (Göttingen: Van den Hoeck und Ruprecht, 1959); H.H. Eggebrecht, 'Zum Figur-Begriff der Musica Poetica,' Archiv für Musikwissenschaft, 16 (1959), 57-69.

23 Cf. Adelheid Beckmann, Motive und Formen der deutschen Lyrik des 17 Jahrhunderts und ihre Entsprechungen in der französischen Lyrik seit Ronsard (Tübingen: M. Niemeyer, 1960), pp. 20, 30, 89-90, 130-31; cf. also Erich Trunz, 'Weltbild und Dichtung im deutschen Barock,' Aus der Welt des Barock, ed. Richard Alewyn (Stuttgart: Metzler, 1957), pp. 19-20, 30-31.

24 Cf. Mattheson, Capellmeister, chapter $13 \$ 61$, p. 103 \$29; Johann Mattheson, Critica Musica, vol. 1 (Hamburg: im Selbstverlag, 1722), p. 199.

25 For a comprehensive list, cf. Unger, pp. 156-159 and Schmitz, 'Figuren,' pp. 176-77.

26 Verbal rhetoric underwent in itself a classicist transformation in Germany after 1700. Under the influence of Leibniz, Thomasius, Hallbauer, Gottsched and others it assumed greater clarity, directness and simplicity. Cf. Ursula Stötzer, Deutsche Redekunst im 17. und 18. Jahrhundert (Halle/Saale: M. Niemeyer, 1962), pp. 73-77, 90, 184-203. 
Cf. Blume, Renaissance and Baroque Music, pp. 111-12.

28 Mozart wrote in 1781: In the opera poetry should become the obedient daughter of music. ...' Cf. Friedrich Blume, 'Wolfgang Amadeus Mozart,' Die Musik in Geschichte und Gegenwart, ed. Friedrich Blume, 9 (Kassel: Bärenreiter, 1961), 791, 795.

29 Cf. Friedrich Blume, 'Die Musik des Barock in Deutschland,' Syntagma Musicologicum, ed. Martin Ruhnke (Kassel: Bärenreiter, 1963), pp. 195-96; Friedrich Blume, 'J.S. Bach,' Die Musik in Geschichte und Gegenwart, ed. Friedrich Blume (Kassel: Bärenreiter, 1949), p. 103; Walther Blankenburg, 'Bach und die Aufklärung,' Bach-Gedenkschrift, ed. Karl Matthaei (Zürich: Atlantis, 1950), p. 31.

30 Cf. Blume, 'Die Musik des Barock in Deutschland,' p. 195.

31 Printed in Philipp Spitta, J.S. Bach, 5th edition (Wiesbaden: Breitkopf und Härtel, 1962), vol. 2, pp. 915-16.

$32 \mathrm{Cf}$. the controversy following Blume's 'new Bach concept': Friedrich Blume, 'Umrisse eines neuen Bach-Bildes,' Musica (1962), pp. 169-76.

33 Johann Nicolaus Forkel, J.S. Bach: Leben, Kunst und Kunstwerke (Leipzig: Hoffmeister und Kühnel, 1802), pp. 24-25.

34 Birnbaum mentioned this in his defence of Bach against Scheibe, who favoured the new eighteenth century rationalistic and naturalistic tendencies in rhetoric and musical composition. Bach's musical rhetoric, which included various archaic tropes and figures and a complex religious symbolism, was unacceptable to Scheibe. Cf. Johann Adolph Scheibe, Critischer Musikus, 2nd edition (Leipzig: Breitkopf, 1745), p. 997.

35 Cf. Blume, 'J.S. Bach,' p. 1028.

36 Cf. Wilibald Gurlitt, Musik und Rhetorik: Hinweise auf ihre geschichtliche Grundlageeinheit,' Helicon Revue internationale de la literature, 5 (1944), 69.

37 Cf. also Kloppers, pp. 78-90, 113-21.

38 Mattheson, Critica Musica, vol. 1, p. 199.

39 As summarized in Blume, Renaissance and Baroque Music, pp. 112-16; also Blume, 'J.S. Bach,' pp. 1030-31.

40 See, i.e., Huber, pp. 45-47.

41 Karl H. Wörner, Geschichte der Musik (Göttingen: Van den Hoeck und Ruprecht, 1965), pp. 147-149; cf. also Blume, Renaissance and Baroque Music, pp. 5, 6, 10.

42 Marin Mersenne, Harmonie Universelle (Paris, 1636; reprint edition, Paris: Centre national de la recherche scientifique, 1963).

43 Kircher, Musurgia Universalis.

44 Andreas Werckmeister, Musicalische Paradoxal-Discourse oder Ungemeine Vorstellungen ... (Quedlinburg: T.P. Calvisius, 1707).

45 Blume, 'J.S. Bach,' p. 1030.

46 Cf. especially Friedrich Smend, J.S. Bach bei seinem Namen gerufen: Eine Noteninschrift und ihre Deutung (Kassel: Bärenreiter, 1950).

47 Scheibe, p. 890. 